\title{
Monitoring of Methodical Competence of Mathematics Teachers' Indicators and Levels in the Conditions of the Partnership of Pedagogical University and School
}

\author{
Olha Matiash \\ Vinnytsia Mykhailo Kotsiubynskyi State Pedagogical University \\ Liubov Mykhailenko \\ Vinnytsia Mykhailo Kotsiubynskyi State Pedagogical University \\ Roksolana Milian \\ Ternopil Volodymyr Hnatiuk National Pedagogical University \\ Viacheslav Olshevskyi \\ Vinnytsia Mykhailo Kotsiubynskyi State Pedagogical University
}

The article proves the effectiveness of the experimental system of the partnership between a pedagogical university and school. We suggested a personal approach to monitoring the indicators and levels of methodological competence of mathematics teachers in terms of collaboration. Methodological competence indicators in teaching pupils mathematics, the formation of which is the most possible in partnership between a pedagogical university and a school, are determined based on the analysis of 12 educational programs for mathematics teachers, thorough analysis of Ukrainian scientists' research results, based on questionnaires of students, teachers, and lecturers, as well as on our experimental research.

Keywords: development of method competence of a teacher of mathematics, collaboration of teachers, formation of method competence of a future teacher, partnership of school and university

\section{INTRODUCTION}

The international pedagogical community actively discusses mathematics teachers' professional training and assessments of teachers' competencies. Modern international publications cover current issues of teachers' knowledge and skills (Shulman, 2013; Potari, 2016; Tatto, 2012; Tatto, 2008; Hilligus, 2009); content and structure of professional development of teachers (Hoth, 2017; Hoth, 2017; Buchholtz, 2018; Ingvarson, 2013); models of development of mathematics teachers' methodical competences (Hilligus, 2009; Baumert, 2013; Kunter, 2011; Schwarz, 2019); development of professional identities of future mathematics teachers (Hilligus, 2009; Erens, 2019); pedagogical experience and its impact on the mathematics teachers' development of skills (Li, 2012; Matos, 2009; Potari, 2019; Strutchens, 2017), ect. 
Analysis of scientific sources devoted to the diagnosis of mathematics teachers' methodological competence (Hoth, 2017; Hoth, 2016; Ingvarson. 2013), and the development of systems of pedagogical universities and secondary schools collaboration (Buchholtz, 2018; Thurm, 2020; Daemen, 2020; Jackson, 2018; Martin, 2015; Novotná, 2018), allowed to distinguish the main structural components of the formation of mathematics teachers' methodological competence in partnership between pedagogical university and school. They are motivational, communicative, actional, and reflexive.

Nowadays, we are researching the partnership system between a pedagogical university and a school to develop the mathematics teachers' methodological competence and the formation of their methodological competence.

To prove the partnership experimental system's effectiveness between a pedagogical university and a school, we understood the need to monitor the indicators and levels of mathematics teachers' methodological competence in this partnership. In the scientific and pedagogical literature, we have not found precise research results on changes in collaboration indicators and levels. Therefore, this article aims to present the results of their research on indicators and levels of methodological competence of mathematics teachers in partnership with a pedagogical university and a school.

\section{METHODOLOGY}

Let us consider the technology we used to determine the indicators of teachers' methodological competence in teaching mathematics to pupils who can develop in a partnership between a pedagogical university and a school. We first clarified the list of methodological competence indicators in teaching mathematics to pupils (Table 1.1), which we identified based on the analysis of the works of Ukrainian scientists (Matiash, 2020; Akulenko, 2015; Achkan, 2018; Hodovaniuk, 2020; Kuzminskyi, 2014; Kolomiiets, 2016; Matiash, 2015; Motorina, 2005).

We have compiled this summary list in obedience to the descriptors of the national qualifications framework.

TABLE 1

\section{SUMMARY LIST OF INDICATORS OF METHODOLOGICAL COMPETENCE IN TEACHING MATHEMATICS (BASED ON THE UKRAINIAN SCIENTISTS' RESEARCH RESULTS)}

\begin{tabular}{|c|c|c|c|}
\hline Kno & Skills & Inication & $\begin{array}{l}\text { Responsibility and } \\
\text { autonomy }\end{array}$ \\
\hline $\begin{array}{l}\text { - knowledge and } \\
\text { understanding the } \\
\text { basic concepts of } \\
\text { methods of teaching } \\
\text { mathematics; } \\
\text { - knowledge and } \\
\text { understanding of the } \\
\text { tasks of methodical } \\
\text { activity of a math } \\
\text { teacher; } \\
\text { - knowledge of the } \\
\text { goals and objectives } \\
\text { of teaching math at } \\
\text { school; } \\
\text { - knowledge of the } \\
\text { peculiarities of the }\end{array}$ & $\begin{array}{l}\text { positive attitude to } \\
\text { teaching math; } \\
\text { - ability to structure } \\
\text { educational material } \\
\text { and develop effective } \\
\text { systems of lessons in } \\
\text { mathematics at } \\
\text { school; } \\
\text { - ability to effectively } \\
\text { use theoretical, } \\
\text { methodological } \\
\text { knowledge in } \\
\text { practice; } \\
\text { - ability to perform } \\
\text { logical and didactic }\end{array}$ & $\begin{array}{l}\text { - ability to positively } \\
\text { influence students } \\
\text { through the } \\
\text { establishment of } \\
\text { subject relations in } \\
\text { the educational } \\
\text { process; } \\
\text { - readiness to } \\
\text { communicate with } \\
\text { colleagues on the } \\
\text { problem of effective } \\
\text { teaching of math to } \\
\text { pupils; } \\
\text { - ability to } \\
\text { communicate with } \\
\text { colleagues on the }\end{array}$ & $\begin{array}{l}\text { - understanding the } \\
\text { essence of the } \\
\text { methodological } \\
\text { competence of a } \\
\text { mathematics teacher; } \\
\text { - awareness of the need } \\
\text { for self-education, } \\
\text { self-development, } \\
\text { self-improvement in } \\
\text { teaching mathematics } \\
\text { to pupils; } \\
\text { - demonstration and } \\
\text { the ability to } \\
\text { substantiate one's } \\
\text { own methodological } \\
\text { beliefs; }\end{array}$ \\
\hline
\end{tabular}




\begin{tabular}{|c|c|c|c|}
\hline 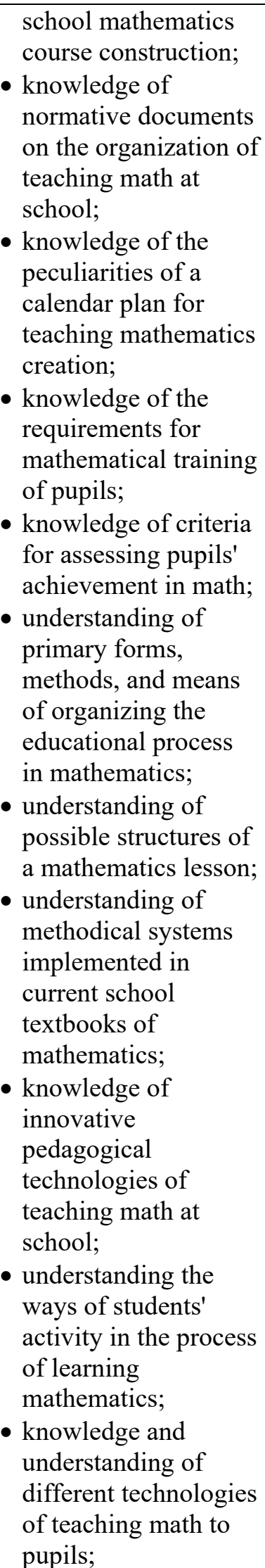 & $\begin{array}{l}\text { analysis of the } \\
\text { educational topic; } \\
\text { - ability to determine } \\
\text { the types, methods, } \\
\text { and means of } \\
\text { monitoring students' } \\
\text { achievements in } \\
\text { mathematics; } \\
\text { - ability to organize } \\
\text { students' learning } \\
\text { activities while } \\
\text { studying new } \\
\text { concepts, theorems; } \\
\text { - ability to organize } \\
\text { students' learning } \\
\text { activities in solving } \\
\text { problems; } \\
\text { - ability to plan a math } \\
\text { lesson; } \\
\text { - ability to create } \\
\text { conditions in the } \\
\text { process of teaching } \\
\text { mathematics for the } \\
\text { development of the } \\
\text { method of pupils' } \\
\text { mental activity; } \\
\text { - ability to conduct a } \\
\text { quality math lesson at } \\
\text { school, } \\
\text { - ability to } \\
\text { methodically use } \\
\text { information } \\
\text { technologies; } \\
\text { systematic } \\
\text { knowledge and skills } \\
\text { - ability to form and } \\
\text { develop pupils' } \\
\text { mathematical } \\
\text { competence to prove } \\
\text { mathematical } \\
\text { statements; } \\
\text { ability to form and } \\
\text { develop pupils' } \\
\text { mathematical } \\
\text { competence in } \\
\text { various methods and } \\
\text { ablins solving } \\
\text { ablic } \\
\text { and }\end{array}$ & $\begin{array}{l}\text { problem of } \\
\text { organizing a modern } \\
\text { math lesson and } \\
\text { studying some of its } \\
\text { topics; } \\
\text { - ability to present own } \\
\text { developments of } \\
\text { different types of } \\
\text { mathematics lessons; } \\
\text { - ability to carry out an } \\
\text { extensive analysis of } \\
\text { mathematics lessons } \\
\text { methodically; } \\
\text { - ability to discuss } \\
\text { effective methods, } \\
\text { techniques, and tools } \\
\text { for teaching math; } \\
\text { - ability to demonstrate } \\
\text { readiness for self- } \\
\text { education, } \\
\text { methodical self- } \\
\text { improvement, } \\
\text { methodical self- } \\
\text { development; } \\
\text { - ability to cooperate } \\
\text { with stakeholders to } \\
\text { achieve the set prices } \\
\text { in the teaching of } \\
\text { mathematics to } \\
\text { pupils; } \\
\text { - ability to actively and } \\
\text { creatively interact in } \\
\text { the process of pair } \\
\text { and group methodical } \\
\text { activity; } \\
\text { - ability to demonstrate } \\
\text { flexibility and } \\
\text { strength of } \\
\text { methodological } \\
\text { management - } \\
\text { knowledge; } \\
\text { possession of speech- } \\
\text { subject competence } \\
\text { in the systems } \\
\text { "teacher - pupil", } \\
\text { "teacher - teacher", } \\
\text { teacher - pupil } \\
\text { teacher - } \\
\text { mer team", }\end{array}$ & $\begin{array}{l}\text { - desire to achieve a } \\
\text { high level of } \\
\text { methodological } \\
\text { training; } \\
\text { - understanding of the } \\
\text { importance of } \\
\text { methodological } \\
\text { competence; } \\
\text { - conscious desire to } \\
\text { master the } \\
\text { methodological } \\
\text { skills; } \\
\text { - valuable attitude to } \\
\text { the professional } \\
\text { ideal; } \\
\text { - readiness to look for } \\
\text { ways to solve } \\
\text { educational problems } \\
\text { that arise in } \\
\text { connection with the } \\
\text { education system } \\
\text { reform in general, } \\
\text { and mathematics } \\
\text { education in } \\
\text { particular; } \\
\text { - interest in mastering } \\
\text { new methodological } \\
\text { knowledge and skills; } \\
\text { - ability to critically } \\
\text { analyze sustainable } \\
\text { methodological } \\
\text { views; } \\
\text { - readiness to build a } \\
\text { personally weighty, } \\
\text { relationships between } \\
\text { different components } \\
\text { and factors that affect } \\
\text { the effectiveness of } \\
\text { own methodical } \\
\text { system of teaching } \\
\text { math to pupils; } \\
\text { - the ability to show } \\
\text { confidence in the } \\
\text { organization and in } \\
\text { the implementation } \\
\text { of methodological } \\
\text { letivities during the } \\
\text { the ability to analyze, }\end{array}$ \\
\hline
\end{tabular}




\begin{tabular}{|c|c|c|c|}
\hline $\begin{array}{l}\text { - knowledge of } \\
\text { advanced } \\
\text { pedagogical } \\
\text { experience of } \\
\text { teachers-practitioners } \\
\text { on the problems of } \\
\text { organizing a modern } \\
\text { lesson of math and } \\
\text { studying its topics; } \\
\text { - knowledge of the } \\
\text { peculiarities of the } \\
\text { contemporary } \\
\text { information } \\
\text { technologies use in } \\
\text { the teaching of math; } \\
\text { - understanding the } \\
\text { essence, purpose, and } \\
\text { principles of the } \\
\text { organization of } \\
\text { teaching math at } \\
\text { school level } \\
\text { differentiation; } \\
\text { - understanding of the } \\
\text { essence, purpose, and } \\
\text { regulations of the } \\
\text { organization of } \\
\text { specialized } \\
\text { differentiation of } \\
\text { teaching math at } \\
\text { schoctive courses } \\
\text { content for classes of } \\
\text { different } \\
\text { - knowledge of the } \\
\text { specifics of various } \\
\text { teaching technologies } \\
\text { and methods of their } \\
\text { creation and } \\
\text { application in the } \\
\text { process of teaching } \\
\text { mathematics; } \\
\text { - knowledge of forms } \\
\text { of monitoring, } \\
\text { control, evaluation, } \\
\text { and correction of } \\
\text { pupils' academic } \\
\text { achievements in the } \\
\text { process of learning } \\
\text { knathematics, } \\
\text { aledge of the }\end{array}$ & $\begin{array}{l}\text { of pupils in } \\
\text { mathematics; } \\
\text { - ability to form and } \\
\text { develop ways for } \\
\text { successful application } \\
\text { of knowledge and } \\
\text { skills in mathematics } \\
\text { for solving practical } \\
\text { and applied } \\
\text { problems; } \\
\text { - ability to form and } \\
\text { develop mathematical } \\
\text { competence of pupils } \\
\text { in classes of the in- } \\
\text { depth study of } \\
\text { mathematics. }\end{array}$ & $\begin{array}{l}\text { - ability to use } \\
\text { mathematical terms } \\
\text { correctly; } \\
\text { - the ability to show } \\
\text { healthy emotional } \\
\text { reactions to } \\
\text { professional failures } \\
\text { or achievements. }\end{array}$ & $\begin{array}{l}\text { teaching mathematics } \\
\text { in school; } \\
\text { - ability to model, } \\
\text { predict, design, and } \\
\text { construct in the } \\
\text { process of teaching } \\
\text { math pupils; } \\
\text { - ability to determine } \\
\text { the necessary system } \\
\text { of methodical actions } \\
\text { in known, unknown, } \\
\text { non-standard } \\
\text { situations based on } \\
\text { systematization, } \\
\text { generalization, and } \\
\text { analysis of facts; } \\
\text { - ability to realize the } \\
\text { purpose of the } \\
\text { methodical activity in } \\
\text { the form of the } \\
\text { expected result; } \\
\text { - ability to control and } \\
\text { evaluate own } \\
\text { methodical activity; } \\
\text { - ability to } \\
\text { independently and } \\
\text { impartially perceive } \\
\text { new methodological } \\
\text { knowledge about the } \\
\text { problem through the } \\
\text { prism of their own } \\
\text { methodological } \\
\text { rethink educational } \\
\text { material; } \\
\text { to correctly } \\
\text { determine the causes } \\
\text { of failure in teaching } \\
\text { beliefs; } \\
\text { ability to generate } \\
\text { new ideas aimed at } \\
\text { improving the } \\
\text { process of learning } \\
\text { mathematics; } \\
\text { independence and } \\
\text { creative solution of } \\
\text { ability to creative } \\
\text { absional tasks; } \\
\text { ofity to creatively }\end{array}$ \\
\hline
\end{tabular}


specialization and

features of the

elective courses in

mathematics

organization and

conduction;

- understanding the

peculiarities of the

organization of

pupils' educational

and cognitive

activities in the

process of learning

mathematics;

- knowledge of the

questions typology

and their formulation

features during

teaching

mathematics;

- knowledge of the

peculiarities of the

organization of

mathematics

extracurricular at

school.

At first, we should note that the vast majority of teachers' methodological competence in teaching mathematics to pupils (selected based on Ukrainian scientists' research results) relates to such descriptors of the national qualifications framework as knowledge, autonomy, and responsibility. Among indicators of methodological competence listed in Table 1, we have identified those, the formation and development of which, in our opinion, is the most possible in partnership between a pedagogical university and a school. The selected list is presented in the form of Table 2:

TABLE 2

\section{INDICATORS OF METHODOLOGICAL COMPETENCE IN TEACHING MATHEMATICS, THE FORMATION OF WHICH IS POSSIBLE IN PARTNERSHIP BETWEEN A PEDAGOGICAL UNIVERSITY AND A SCHOOL}

\begin{tabular}{|c|c|c|c|}
\hline Knowledge & Skills & Communication & $\begin{array}{l}\text { Responsibility and } \\
\text { autonomy }\end{array}$ \\
\hline $\begin{array}{l}\text { - understanding the } \\
\text { tasks of methodical } \\
\text { activity of a } \\
\text { mathematics teacher; } \\
\text { - knowledge of } \\
\text { normative documents } \\
\text { on the organization of } \\
\text { teaching mathematics } \\
\text { at school; }\end{array}$ & $\begin{array}{l}\text { - ability to create } \\
\text { conditions in the } \\
\text { process of teaching } \\
\text { mathematics for the } \\
\text { methods of pupils' } \\
\text { mental activity } \\
\text { development; }\end{array}$ & $\begin{array}{l}\text { - readiness to } \\
\text { communicate with } \\
\text { colleagues on the } \\
\text { problems of effective } \\
\text { teaching of } \\
\text { mathematics to } \\
\text { pupils; } \\
\text { - ability to } \\
\text { communicate with }\end{array}$ & $\begin{array}{l}\text { - understanding the } \\
\text { essence of the } \\
\text { methodological } \\
\text { competence of a } \\
\text { mathematics teacher; } \\
\text { - awareness of the need } \\
\text { for self-education, } \\
\text { self-development, } \\
\text { self-improvement in }\end{array}$ \\
\hline
\end{tabular}




\begin{tabular}{|c|c|c|c|}
\hline 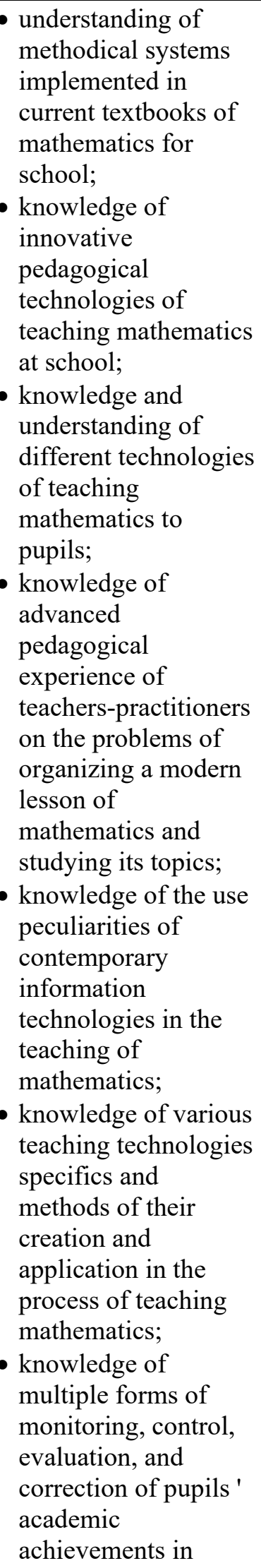 & $\begin{array}{l}\text { - the ability to conduct } \\
\text { a quality math lesson } \\
\text { at school; } \\
\text { - ability to } \\
\text { methodically use } \\
\text { information } \\
\text { technologies; } \\
\text { - ability to form and } \\
\text { develop holistic, } \\
\text { systematic } \\
\text { knowledge and skills } \\
\text { of pupils in } \\
\text { mathematics; } \\
\text { - ability to form and } \\
\text { develop ways of } \\
\text { pupils ' activity on } \\
\text { the successful } \\
\text { application of } \\
\text { knowledge and skills } \\
\text { in mathematics for } \\
\text { solving practical and } \\
\text { applied problems. }\end{array}$ & $\begin{array}{l}\text { colleagues on the } \\
\text { difficulties of } \\
\text { organizing a modern } \\
\text { maths lesson and } \\
\text { studying some of its } \\
\text { topics; } \\
\text { - ability to present own } \\
\text { developments of } \\
\text { different types of } \\
\text { mathematics lessons; } \\
\text { - ability to } \\
\text { methodically carry } \\
\text { out an extensive } \\
\text { analysis of a } \\
\text { mathematics lesson; } \\
\text { - ability to discuss } \\
\text { effective methods, } \\
\text { techniques, and tools } \\
\text { for teaching } \\
\text { mathematics; } \\
\text { - ability to demonstrate } \\
\text { readiness for self- } \\
\text { education, } \\
\text { methodical self- } \\
\text { improvement, } \\
\text { methodical self- } \\
\text { development; } \\
\text { - ability to cooperate } \\
\text { with stakeholders to } \\
\text { achieve goals in } \\
\text { teaching mathematics } \\
\text { to pupils; } \\
\text { reactions to } \\
\text { professional failures } \\
\text { or achievements. } \\
\text { creatively interact in } \\
\text { the process of pair } \\
\text { and group methodical } \\
\text { activity; } \\
\text { - ability to demonstrate } \\
\text { flexibility and } \\
\text { strength of } \\
\text { methodological } \\
\text { the show } \\
\text { to }\end{array}$ & $\begin{array}{l}\text { teaching math to } \\
\text { pupils; } \\
\text { - demonstration and } \\
\text { the ability to } \\
\text { substantiate one's } \\
\text { own methodological } \\
\text { beliefs; } \\
\text { - desire to achieve a } \\
\text { high level of } \\
\text { methodological } \\
\text { training; } \\
\text { - conscious willingness } \\
\text { to master the } \\
\text { methodological skills } \\
\text { - readiness to look for } \\
\text { ways to solve } \\
\text { educational problems } \\
\text { that arise in } \\
\text { connection with the } \\
\text { education system } \\
\text { reform in general, } \\
\text { and math education } \\
\text { in particular; } \\
\text { - interest in mastering } \\
\text { new methodological } \\
\text { knowledge and skills; } \\
\text { - ability to critically } \\
\text { analyze sustainable } \\
\text { methodological } \\
\text { views; } \\
\text { - readiness to build a } \\
\text { personally weighty, } \\
\text { own methodical } \\
\text { system of teaching } \\
\text { the necessary system } \\
\text { of methodical actions } \\
\text { in known, unknown, } \\
\text { non-standard } \\
\text { situations based on } \\
\text { systematization, } \\
\text { the ability to analyze, } \\
\text { identify and establish } \\
\text { relationships between } \\
\text { different components } \\
\text { and factors that affect } \\
\text { the effectiveness of } \\
\text { teaching math in } \\
\text { abool; }\end{array}$ \\
\hline
\end{tabular}




\begin{tabular}{|c|c|}
\hline $\begin{array}{l}\text { learning } \\
\text { mathematics. }\end{array}$ & $\begin{array}{l}\text { generalization, and } \\
\text { analysis of facts; } \\
\text { - ability to control and } \\
\text { evaluate own } \\
\text { methodical activity; } \\
\text { - the ability to } \\
\text { independently and } \\
\text { impartially perceive } \\
\text { new methodological } \\
\text { knowledge or } \\
\text { problems through the } \\
\text { prism of their own } \\
\text { methodological } \\
\text { beliefs, } \\
\text { - ability to generate } \\
\text { new ideas aimed at } \\
\text { improving the } \\
\text { process of learning } \\
\text { math; } \\
\text { - ability to creative } \\
\text { independence and } \\
\text { creative solution of } \\
\text { professional tasks; } \\
\text { - developed self- } \\
\text { criticism, the ability } \\
\text { to correctly } \\
\text { determine the causes } \\
\text { of failure in teaching } \\
\text { math to pupils. }\end{array}$ \\
\hline
\end{tabular}

It is easy to see that the proposed transition from Table 1 to Table 2 allows us to formulate the hypothesis that in partnership between a pedagogical university and a school, one can theoretically provide favorable conditions for the formation and development of teachers' methodological competence indicators in teaching mathematics. These indicators mostly belong to such descriptors of the national qualifications framework as knowledge, communication, responsibility, and autonomy. To identify methodological competence indicators in teaching mathematics to pupils, the formation and development of which is the most possible in partnership between a pedagogical university and a school, we will also consider the requirements of educational and professional training programs for mathematics teachers in higher education. We conducted a detailed analysis of educational and professional training programs for mathematics teachers in twelve pedagogical universities of Ukraine: Berdyansk State Pedagogical University; Vinnytsia Mykhailo Kotsyubynsky State Pedagogical University; Glukhiv Oleksandr Dovzhenko National Pedagogical University; State Higher Educational Institution "Donbas State Pedagogical University"; Pereyaslav-Khmelnytsky Hryhoriy Skovoroda State Pedagogical University; State Institution "South Ukrainian K.D. Ushinsky National Pedagogical University"; Kryvyi Rih State Pedagogical University; Melitopol Bohdan Khmelnytsky State Pedagogical University; Poltava V.G. Korolenko National Pedagogical University; Ternopil Volodymyr Hnatyuk National Pedagogical University; Uman Pavlo Tychyna State Pedagogical University; Kharkiv H.S. Skovoroda National Pedagogical University. Based on this analysis, we have formed a generalized list of methodological competence indicators in teaching mathematics to pupils in the form of Table 3. 
TABLE 3

SUMMARY LIST OF METHODOLOGICAL COMPETENCE INDICATORS IN TEACHING MATHEMATICS TO PUPILS (BASED ON THE EDUCATIONAL PROGRAMS ANALYSIS)

\begin{tabular}{|c|c|c|c|}
\hline Knowledge & kills & Communication & $\begin{array}{l}\text { Responsibility and } \\
\text { autonomy }\end{array}$ \\
\hline $\begin{array}{l}\text { - knows and freely } \\
\text { operates the main } \\
\text { categories and } \\
\text { concepts of methods } \\
\text { of teaching } \\
\text { mathematics; } \\
\text { - knows the historical } \\
\text { mathematics stages } \\
\text { of development and } \\
\text { methods of teaching } \\
\text { mathematics; } \\
\text { - knows the conceptual } \\
\text { foundations of school } \\
\text { education in } \\
\text { mathematics, goals, } \\
\text { and objectives of } \\
\text { teaching mathematics } \\
\text { at school; } \\
\text { - knows the main types } \\
\text { and content of } \\
\text { mathematics teachers } \\
\text { activity; } \\
\text { - knows and can } \\
\text { explain the } \\
\text { peculiarities of the } \\
\text { organization of } \\
\text { pupils' learning at } \\
\text { different specific } \\
\text { stages of the } \\
\text { mathematics lesson, } \\
\text { taking into account } \\
\text { the age } \\
\text { characteristics of } \\
\text { students and the } \\
\text { specifics of } \\
\text { educational goals; } \\
\text { - knows the forms and } \\
\text { methods of teaching } \\
\text { pupils in mathematics } \\
\text { lessons and } \\
\text { extracurricular } \\
\text { activities; } \\
\text { - }\end{array}$ & $\begin{array}{l}\text { - can solve problems of } \\
\text { different levels of } \\
\text { complexity of the } \\
\text { school maths course; } \\
\text { - can use } \\
\text { recommendations on } \\
\text { teaching mathematics } \\
\text { methods to } \\
\text { implement an } \\
\text { educational program } \\
\text { in mathematics in a } \\
\text { secondary school; } \\
\text { - understands and can } \\
\text { apply the } \\
\text { introductory } \\
\text { theoretical provisions } \\
\text { of the methodology } \\
\text { of teaching math; } \\
\text { - has a culture of } \\
\text { mathematical } \\
\text { thinking, logic, and } \\
\text { algorithmics; } \\
\text { - can implement } \\
\text { modern innovative } \\
\text { learning } \\
\text { technologies; } \\
\text { - can carry out } \\
\text { methodical analysis } \\
\text { of educational } \\
\text { material of school } \\
\text { maths textbooks; } \\
\text { - can design and } \\
\text { conduct a math } \\
\text { lesson at the } \\
\text { appropriate level; } \\
\text { - can use the method of } \\
\text { extracurricular } \\
\text { activities in math; } \\
\text { - can track the } \\
\text { dynamics of personal } \\
\text { development of } \\
\text { pupils in } \\
\text { mathlessons; }\end{array}$ & $\begin{array}{l}\text { - can communicate } \\
\text { effectively in the } \\
\text { process of teaching } \\
\text { mathematics to } \\
\text { pupils; } \\
\text { - knows the basics of } \\
\text { professional speech } \\
\text { culture in teaching } \\
\text { mathematics at } \\
\text { school; } \\
\text { - can present their own } \\
\text { experience of } \\
\text { teaching mathematics } \\
\text { to pupils; } \\
\text { - has the skills to } \\
\text { prepare scientific and } \\
\text { methodological } \\
\text { materials; } \\
\text { - can demonstrate } \\
\text { fragments of the } \\
\text { organization of } \\
\text { teaching mathematics } \\
\text { to pupils at different } \\
\text { specific stages of a } \\
\text { mathematics lesson; } \\
\text { - can organize } \\
\text { cooperation with } \\
\text { pupils, support their } \\
\text { activity, initiative, } \\
\text { independence, and } \\
\text { creative abilities. }\end{array}$ & $\begin{array}{l}\text { - can perceive } \\
\text { information, } \\
\text { creatively rethink it } \\
\text { and apply it in the } \\
\text { process of } \\
\text { professional activity; } \\
\text { - can analyze, design, } \\
\text { implement and } \\
\text { improve support for } \\
\text { teaching and learning } \\
\text { mathematics to } \\
\text { pupils; } \\
\text { - appreciates and can } \\
\text { develop their own } \\
\text { mathematical and } \\
\text { methodological } \\
\text { competencies and is } \\
\text { aware of the } \\
\text { responsibility for } \\
\text { their level; } \\
\text { can find, analyze, } \\
\text { summarize and } \\
\text { systematize the data } \\
\text { needed to present } \\
\text { their own experience; } \\
\text { can use } \\
\text { methodological } \\
\text { knowledge and } \\
\text { practical skills for } \\
\text { research in the } \\
\text { pedagogical field; } \\
\text { - can distinguish, } \\
\text { critically } \\
\text { comprehend, use } \\
\text { traditional and } \\
\text { innovative } \\
\text { approaches, } \\
\text { principles, methods, } \\
\text { techniques of } \\
\text { teaching and } \\
\text { organizing } \\
\text { methodological } \\
\text { activities; }\end{array}$ \\
\hline
\end{tabular}




\begin{tabular}{|c|c|c|}
\hline $\begin{array}{l}\text { features of teaching } \\
\text { mathematics to } \\
\text { various groups of } \\
\text { pupils. }\end{array}$ & $\begin{array}{l}\text { - can use the method of } \\
\text { preparing pupils for } \\
\text { math competitions } \\
\text { and tournaments; } \\
\text { - can organize remote } \\
\text { and independent } \\
\text { work in math using } \\
\text { modern innovative } \\
\text { techniques and } \\
\text { teaching } \\
\text { technologies; } \\
\text { - can use the } \\
\text { technology of } \\
\text { organization in the } \\
\text { process of } \\
\text { educational and } \\
\text { research activities of } \\
\text { pupils in the lessons } \\
\text { and extracurricular } \\
\text { activities in math; } \\
\text { - can apply modern } \\
\text { techniques and } \\
\text { technologies, } \\
\text { including information } \\
\text { and communication } \\
\text { in class and } \\
\text { extracurricular } \\
\text { activities; } \\
\text { - can give examples in } \\
\text { teaching math; } \\
\text { - can identify errors } \\
\text { abilities to create } \\
\text { the knortcomings in } \\
\text { individual work; } \\
\text { skills of pupils in } \\
\text { math, in the logic of } \\
\text { reasoning, explain the } \\
\text { difference between } \\
\text { facts and } \\
\text { consequences; } \\
\text { - can apply methods of } \\
\text { diagnosing students' } \\
\text { achievements in } \\
\text { math, select and } \\
\text { develop tasks for } \\
\text { ansts, independent } \\
\text { - }\end{array}$ & $\begin{array}{l}\text { - can study the } \\
\text { effectiveness of } \\
\text { training, methods, } \\
\text { techniques, and tools } \\
\text { used to teach } \\
\text { mathematics; } \\
\text { - can analyze, design, } \\
\text { implement and } \\
\text { improve educational } \\
\text { and methodological } \\
\text { equipment for } \\
\text { teaching } \\
\text { mathematics; } \\
\text { - can conclude the } \\
\text { effectiveness of the } \\
\text { methods, techniques, } \\
\text { and tools used to } \\
\text { teach mathematics; } \\
\text { - recognize the need at } \\
\text { the present stage of } \\
\text { development of } \\
\text { physical and } \\
\text { mathematical } \\
\text { education in the } \\
\text { formation of pupils ' } \\
\text { ability to apply } \\
\text { interdisciplinary } \\
\text { approaches; } \\
\text { - can accumulate and } \\
\text { systematize various } \\
\text { methods and ways of } \\
\text { solving problems, } \\
\text { banks of crucial } \\
\text { problems, etc.; } \\
\text { - forms the value } \\
\text { aspect of } \\
\text { mathematical } \\
\text { knowledge, } \\
\text { coordinates its } \\
\text { emotional perception } \\
\text { by pupils, develops } \\
\text { and offers various } \\
\text { forms and types of } \\
\text { education of a } \\
\text { positive attitude to } \\
\text { mathematics, and } \\
\text { motivates pupils to } \\
\text { learn its basics and } \\
\text { methods. }\end{array}$ \\
\hline
\end{tabular}


conditions for their

development;

- can demonstrate and

apply the knowledge

of mathematics

necessary for the

formation of

mathematical

competencies of

pupils;

- can form in pupils an

understanding of the

basics of

mathematical

modeling, readiness

to use modeling to

solve problems;

- can establish

interdisciplinary and

intradisciplinary links

while studying

specific topics of the

school course of

math.

A comparative analysis of Table 1 and Table 3 allows us to note that the summarized list of methodological competence indicators in teaching mathematics to pupils, selected based on educational programs analysis, is relatively small (45 indicators). In contrast, a similar list of chosen indicators based on Ukrainian scientists' analysis research amounts to 75 indicators. Secondly, the methodological competence indicators in teaching mathematics to pupils selected based on educational programs' analysis mostly belong to the descriptor - skills/abilities. In our opinion, this can be explained by the fact that Table 3 shows the desired program learning outcomes of future mathematics teachers, and Table 1 is created in the context of methodological activities of mathematics teachers at school. Both situations are relevant for our study, so we have identified from Table 3 those indicators of methodological competence in teaching mathematics to pupils, the formation and development of which, in our opinion, is the most possible in the partnership of pedagogical university and school (Table 4).

TABLE 4

INDICATORS OF METHODOLOGICAL COMPETENCE IN TEACHING MATHEMATICS, THE FORMATION OF WHICH IS POSSIBLE IN PARTNERSHIP BETWEEN A PEDAGOGICAL UNIVERSITY AND A SCHOOL

\begin{tabular}{lccl}
\hline Knowledge & Skills & Communication & $\begin{array}{l}\text { Responsibility and } \\
\text { autonomy }\end{array}$ \\
\hline $\begin{array}{l}\text { - knows and can } \\
\text { explain the }\end{array}$ & • can implement & - can present their own & • can perceive \\
peculiarities of the & learning & experience of & information, \\
$\begin{array}{l}\text { organization of } \\
\text { pupils' learning at }\end{array}$ & technologies; & teaching mathematics & creatively rethink it \\
different stages of the & can carry out & to pupils; & and apply it in the \\
\hline
\end{tabular}




\begin{tabular}{|c|c|c|c|}
\hline $\begin{array}{l}\text { mathematics lesson, } \\
\text { taking into account } \\
\text { the age } \\
\text { characteristics of } \\
\text { pupils and the } \\
\text { specifics of } \\
\text { educational goals; } \\
\text { - knows and } \\
\text { understands the } \\
\text { peculiarities of } \\
\text { teaching mathematics } \\
\text { to various groups of } \\
\text { pupils. }\end{array}$ & $\begin{array}{l}\text { of educational } \\
\text { material of school } \\
\text { textbooks of } \\
\text { mathematics; } \\
\text { - has a method of } \\
\text { preparing students for } \\
\text { math competitions } \\
\text { and tournaments; } \\
\text { - can organize remote } \\
\text { and independent } \\
\text { work using modern } \\
\text { innovative techniques } \\
\text { and teaching } \\
\text { technologies; } \\
\text { - has the organization } \\
\text { technology in the } \\
\text { educational process } \\
\text { of educational and } \\
\text { research activities of } \\
\text { pupils in the lessons } \\
\text { and extracurricular } \\
\text { activities in } \\
\text { mathematics; } \\
\text { - can apply modern } \\
\text { techniques and } \\
\text { technologies, } \\
\text { including information } \\
\text { and communication, } \\
\text { in class and } \\
\text { extracurricular } \\
\text { activities; } \\
\text { - can timely reveal the } \\
\text { unique individuality } \\
\text { and abilities of the } \\
\text { pupils, create } \\
\text { conditions for their } \\
\text { development; } \\
\text { can establish } \\
\text { interdisciplinary and } \\
\text { intradisciplinary links } \\
\text { while studying } \\
\text { specific topics of the } \\
\text { school course of } \\
\text { mathematics. }\end{array}$ & $\begin{array}{l}\text { methodological } \\
\text { materials; } \\
\text { - can demonstrate } \\
\text { fragments of the } \\
\text { organization of } \\
\text { teaching mathematics } \\
\text { to pupils at different } \\
\text { stages of a } \\
\text { mathematics lesson; } \\
\text { - can organize } \\
\text { cooperation with } \\
\text { pupils, support their } \\
\text { activity, initiative, } \\
\text { independence, and } \\
\text { creativity. }\end{array}$ & 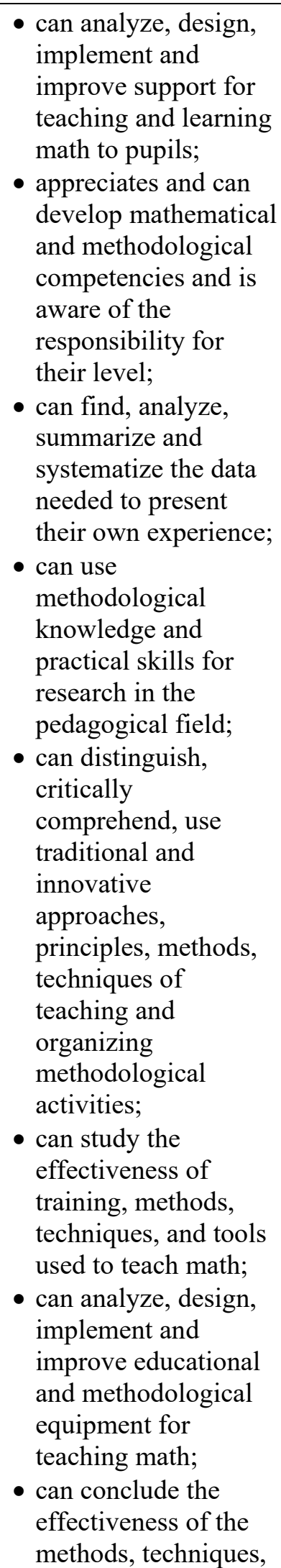 \\
\hline
\end{tabular}




\begin{tabular}{ll}
\hline and tools used to \\
teach mathematics; \\
- recognize the need at \\
the present stage of \\
development of \\
physical and math \\
education in the \\
formation of pupils ' \\
ability to apply \\
interdisciplinary \\
approaches; \\
$\bullet$ can accumulate and \\
systematize various \\
methods and ways of \\
solving problems, \\
banks of crucial \\
problems, etc.; \\
$\bullet$ forms the value \\
aspect of math \\
knowledge, \\
coordinates its \\
emotional perception \\
by pupils, develops \\
and offers various \\
forms and types of \\
education of a \\
positive attitude to \\
math, and motivates \\
pupils to learn its \\
basics and methods. \\
\hline
\end{tabular}

The transition from Table 3 to Table 4, allows us, first of all, to formulate the hypothesis that in terms of the partnership between a pedagogical university and a school, favorable conditions for the formation and development of mathematics teachers' methodological competence indicators can be provided theoretically. These indicators belong to such a descriptor of the national qualifications framework as responsibility and autonomy. Secondly, we discovered a lack of a developed partnership system between a pedagogical university and a school in future mathematics teachers' training in pedagogical universities is one of the reasons for a relatively small list of the competence indicators. The mentioned indicators belong to such a descriptor of the national qualifications framework as communication. Based on a comparative analysis of Table 2 and Table 4, we have created a united list of methodological competence indicators, the formation or development of which, according to our research, is possible in partnership with pedagogical university and school. The list resulted in the questionnaire developed by us (g2g.to/tuAK).

\section{RESULTS}

One hundred and twenty people - three groups of respondents, attended the survey: future mathematics teachers (45), working mathematics teachers (60), those who train mathematics teachers (15). Respondents who took part in the survey had the opportunity to indicate twelve fundamental, in their opinion, indicators of methodological competence in teaching mathematics to pupils, the formation or development of which 
is possible in partnership with a pedagogical university and a school. In Table 5 the indicators of methodical competence of a mathematics teacher, the relevance rating of which exceeded $75 \%$, are indicated.

TABLE 5

QUESTIONNAIRE RESULTS

\begin{tabular}{|c|c|c|}
\hline № & Methodological competence indicators & $\begin{array}{l}\text { Relevance } \\
\text { rating } R, \%\end{array}$ \\
\hline 1. & Knowledge of mathematics teachers' advanced pedagogical experience. & $84,61 \%$ \\
\hline 2. & $\begin{array}{l}\text { Knowledge of innovative pedagogical technologies of teaching mathematics at } \\
\text { school. }\end{array}$ & $83,75 \%$ \\
\hline 3. & $\begin{array}{l}\text { Knowledge and understanding of the organization of pupils ' learning at different } \\
\text { specific stages of the mathematics lesson peculiarities, taking into account pupils ' } \\
\text { age characteristics and the specifics of educational goals. }\end{array}$ & $79,65 \%$ \\
\hline 4. & Ability to use information technologies methodically. & $85,34 \%$ \\
\hline 5. & $\begin{array}{l}\text { Organization technology skills in the educational process of educational and } \\
\text { research activities of pupils in the lesson and extracurricular activities in } \\
\text { mathematics. }\end{array}$ & $83,91 \%$ \\
\hline 6. & $\begin{array}{l}\text { Ability to form and develop holistic, systematic knowledge and skills of pupils in } \\
\text { mathematics. }\end{array}$ & $79,43 \%$ \\
\hline 7. & $\begin{array}{l}\text { Ability to organize remote and independent work in mathematics using modern } \\
\text { innovative techniques and teaching technologies. }\end{array}$ & $79,37 \%$ \\
\hline 8. & Willingness and ability to present their own methodological experience. & $86,23 \%$ \\
\hline 9. & $\begin{array}{l}\text { Willingness and ability to communicate with colleagues on effective teaching of } \\
\text { mathematics to pupils problems. }\end{array}$ & $83,68 \%$ \\
\hline 10 . & Willingness and ability to prepare teaching materials & $82,57 \%$ \\
\hline 11. & $\begin{array}{l}\text { Willingness and ability to work with stakeholders to achieve goals in teaching } \\
\text { mathematics to pupils. }\end{array}$ & $81,93 \%$ \\
\hline 12. & $\begin{array}{l}\text { Ability to demonstrate readiness for self-education, methodical self-improvement, } \\
\text { methodical self-development. }\end{array}$ & $79,48 \%$ \\
\hline 13. & $\begin{array}{l}\text { Ability to organize cooperation with pupils, support their activity, initiative, } \\
\text { independence, and their creative abilities. }\end{array}$ & $78,39 \%$ \\
\hline 14. & $\begin{array}{l}\text { Ability to show healthy emotional reactions to professional failures or } \\
\text { achievements. }\end{array}$ & $77,94 \%$ \\
\hline 15. & $\begin{array}{l}\text { Awareness of the need for self-education, self-development, self-improvement in } \\
\text { teaching mathematics to pupils. }\end{array}$ & $86,65 \%$ \\
\hline 16. & $\begin{array}{l}\text { Ability to independently and impartially perceive new methodological knowledge } \\
\text { or problems through the prism of their own methodological beliefs. }\end{array}$ & $85,87 \%$ \\
\hline 17. & $\begin{array}{l}\text { Ability to critically comprehend and draw conclusions about the effectiveness of } \\
\text { the methods, techniques, and tools used to teach mathematics. }\end{array}$ & $84,97 \%$ \\
\hline 18. & $\begin{array}{l}\text { Ability to generate new ideas aimed at improving the process of learning } \\
\text { mathematics. }\end{array}$ & $84,12 \%$ \\
\hline 19. & Ability to substantiate their own methodological beliefs. & $79,87 \%$ \\
\hline 20. & Ability to control and evaluate own methodical activity. & $78,63 \%$ \\
\hline 21. & Interest in mastering new methodological knowledge and skills. & $78,11 \%$ \\
\hline 22. & $\begin{array}{l}\text { Readiness to look for ways to solve educational problems arising in connection } \\
\text { with the education system reform in general, and mathematics education in } \\
\text { particular. }\end{array}$ & $77,25 \%$ \\
\hline
\end{tabular}

The relevance rating of indicators $\mathrm{R}$ we determined by the formula (1): 
$R=\frac{n \cdot 100 \%}{N}$

where $n$ - the number of respondents who indicated the relevance of a particular indicator, $N$ - the total number of answers of respondents who took part in the survey.

Thus, to prove the effectiveness of the created system of partnership between a pedagogical university and a school, we have identified the following 12 indicators of methodological competence of teachers in teaching mathematics to pupils:

Knowledge:

- knowledge of innovative pedagogical technologies of teaching mathematics at school;

- knowledge of the advanced pedagogical experience of mathematics teachers.

Skills:

- ability to use information technologies methodically;

- organization technology skills in the educational process of educational and research activities of pupils in the lesson and extracurricular activities in mathematics.

\section{Communication:}

- willingness and ability to present their own methodological experience;

- willingness and ability to communicate with colleagues on effective teaching of mathematics to pupils problems;

- ability to prepare teaching materials;

- willingness and ability to work with stakeholders to achieve goals in teaching mathematics to pupils.

Autonomy and responsibility:

- awareness of the need for self-education, self-development, self-improvement in teaching mathematics to pupils;

- ability to independently and impartially perceive new methodological knowledge or problems through the prism of their own methodological beliefs;

- ability to critically comprehend and draw conclusions about the effectiveness of the methods, techniques, and tools used to teach mathematics;

- ability to generate new ideas aimed at improving the process of learning mathematics.

\section{DISCUSSION}

Monitoring of indicators and levels of methodological competence of mathematics teachers is a systematic tracking of qualitative indicators and levels that characterize teachers' methodological activity in teaching mathematics to pupils. The main purpose of this monitoring is to "take indicators" of the state of methodological competence of mathematics teachers; identify trends in the development of this competence in a partnership between university and school; to provide practical directions of partnership interaction for the increase of levels of methodical competence in mathematics training. In our opinion, the system of identification, support, and development of methodological competence of future and working teachers of mathematics in the partnership of pedagogical university and school can and should be well thought out, motivated, and scientifically-proved. For those capable of methodical activity and not quite capable, with a high level of methodological competence and a low level, conditions should be created that would promote their methodological development and stimulate professional growth.

We consider the concept of differentiation of methodical preparation and methodical activity as search and usage of methodical competence development means, which would lead teachers to a desirable level of acquisition of methodical knowledge, abilities, experience, and beliefs. To create conditions for improving the mathematics teachers' methodological competence levels, it is essential to diagnose these levels in the partnership system between pedagogical university and school. Differentiation of participants in partnership, in our opinion, is possible at the following levels: 
- $\quad$ by the level of methodological knowledge (K1, K2, K3);

- by the level of methodological skills (S1, S2, S3);

- by the level of professional communication $(\mathrm{C} 1, \mathrm{C} 2, \mathrm{C} 3)$;

- by the level of methodological autonomy and responsibility (R1, R2, R3).

$\mathrm{K} 1, \mathrm{~S} 1, \mathrm{C} 1, \mathrm{R} 1$ - these are, respectively, the highest levels of these characteristics, as they are assigned rank 1 . The ranking system, in this case, allows you to read any possible combination. For example, if a set is defined as K1 S2 C3 R2, this means that it is characterized by a high level of methodological knowledge, an average level of methodological skills, a low level of communication, and an intermediate level of methodological autonomy and responsibility. Levels of methodical competence formation and development in terms of the university-school partnership are defined by the ranks sums in the specified characteristics. Consider four groups of sums of levels:

- 4-5 - a high level of methodological competence;

- 6-7 -a higher intermediate level of methodological competence;

- 8 - an intermediate level of methodological competence;

- 9-10 -a lower intermediate level of methodological competence;

- 11-12 - a critical level of methodological competence.

Thus, we distinguish five levels of methodological competence, for example, at the beginning of the partnership: high (4-5), higher intermediate (6-7), intermediate (8), lower intermediate (9-10), critical (11). -12). The organizers' task of the partnership between university and school is to build a partnership system with maximum consideration of the quantitative and qualitative composition of the participants in each event. It is vital to create the content and technology of partnership, taking care of the favorable conditions for the formation and development of methodological competencies of each subgroup's participants.

\section{CONCLUSION}

Under the differentiated approach in the formation and development of mathematics teachers' methodological competence in the system of the partnership of pedagogical university and school, we understand the identification and consideration of indicators and levels of methodological competence of partners to create the most favorable conditions for their improvement. The subjective experience of the one who is studying, improving, or developing must be identified, disclosed, and then coordinated with the partnership's content. The author's system of determination of mathematics teachers' methodical competence levels in terms of the partnership of pedagogical university and school in our experimental research is considered appropriate.

Personality-oriented methodological training or advanced mathematics teachers' training should not aim to form a teacher with predetermined methodological characteristics. The purpose should be to create favorable conditions for the full identification and development of relevant indicators or methodological competence levels for each participant in the partnership. Therefore, it is crucial for the university-school partnership organizers to monitor changes in the partnership participants' indicators and levels of methodological competence.

\section{REFERENCES}

Achkan, V.V. (2018). Pidhotovka maibutnikh uchyteliv matematyky do innovatsiinoi pedahohichnoi diialnosti: Monohrafiia. (Preparation of future teachers of mathematics for innovative pedagogical activity: monograph). Kyiv, Osvita Ukrainy.

Akulenko, I.A. (2015). Prakseolohichno-diialnisnyi pidkhid yak metodolohichna osnova kompetentnisno oriientovanoi metodychnoi pidhotovky maibutnoho vchytelia matematyky. (Praxeologicalactivity approach as a methodological basis of competence-oriented methodical training of future mathematics teachers). Pedahohika Vyshchoi ta Serednoi Shkoly, 46. 
Association of Public \& Land-Grant Universities. (n.d.). Mathematics Teacher Education Partnership. Retrieved February 20, 2020, from https://www.aplu.org/projects-and-initiatives/stemeducation/mathematics-teacher-education-partnership/index.html

Baumert, J., \& Kunter, M. (2013). The COACTIV Model of Teachers' Professional Competence. Cognitive Activation in the Mathematics Classroom and Professional Competence of Teachers, pp. 25-48. https://doi.org/10.1007/978-1-4614-5149-5_2

Buchholtz, N.F., Krosanke, N., Orschulik, A.B., \& Vorhölter, K. (2018). Combining and integrating formative and summative assessment in mathematics teacher education. $Z D M, 50,715-728$. https://doi.org/10.1007/s11858-018-0948-y

Daemen, J., Konings, T., \& van den Bogaart, T. (2020). Secondary School Mathematics Teacher Education in the Netherlands. In M. Van den Heuvel-Panhuizen (Eds.), National Reflections on the Netherlands Didactics of Mathematics. ICME-13 Monographs. Springer, Cham. https://doi.org/10.1007/978-3-030-33824-4_9

Erens, R., \& Eichler, A. (2019). Belief Changes in the Transition from University Studies to School Practice. ICME-13 Monographs, pp. 345-373. https://doi.org/10.1007/978-3-030-13761-8_16

Hilligus, A., Blömeke, S., Kaiser, G., \& Lehmann, R. (Eds.). (2009). Professionelle Kompetenz angehender Lehrerinnen und Lehrer. Wissen, Überzeugungen und Lerngelegenheiten deutscher Mathematikstudierender und -referendare. Erste Ergebnisse zur Wirksamkeit der Lehrerausbildung. ZDM, 41(5). https://doi.org/10.1007/s11858-009-0204-6

Hodovaniuk, T.L. (2020). Dissertation, Uman State Pedagogical University named after Pavel Tychyna.

Hoth, J. (2016). Die Studie TEDS-FU. Situationsbezogene Diagnosekompetenz Von Mathematiklehrkräften, pp. 9-13. https://doi.org/10.1007/978-3-658-13156-2_2

Hoth, J. (2017, February). Situation-specific diagnostic competence of mathematics teachers-a qualitative supplementary study of the TEDS-follow-up project. CERME, 10. Dublin, Ireland.

Hudson, P. (2013). Desirable attributes and practices for mentees: Mentor teachers' expectations. European Journal of Educational Research, 2(3), 107-119.

Ingvarson, L. (2013). An analysis of teacher education context, structure, and quality-assurance arrangements in TEDS-M countries. Amsterdam: International Association for the Evaluation of Educational Achievement (IEA).

Jackson, C., Mohr-Schroeder, M., Cavalcanti, M., Albers, S., Poe, K., Delaney, A., . . Roberts, T. (2018). Prospective mathematics teacher preparation: exploring the use of service learning as a field experience. Fields Math Educ J, 3, 5. https://doi.org/10.1186/s40928-018-0010-5

Kingsley, L., \& Romine, R. (2014). Measuring teaching best practice in the induction years: Development and validation of an item-level assessment. European Journal of Educational Research, 3(2), 87109.

Kolomiiets, A.M., \& Lazarenko, N.I. (2016). Suchasni metodolohichni pidkhody v orhanizatsii vyshchoi pedahohichnoi osvity (Modern methodological approaches in the organization of higher pedagogical education). Naukovi Visnyky Pivdennoukrainskoho Natsionalnoho Pedahohichnoho Universytetu Imeni K. D. Ushynskoho, 3, 47-52.

Kunter, M., Baumert, J., \& Blum W. (2011). Professionelle Kompetenz von Lehrkräften. Münster: Waxmann.

Kuzminskyi, A.I., Tarasenkova, N.A., \& Akulenko, I.A. (2014). Innovatsii v metodolohii metodychnoi pidhotovky maibutnoho vchytelia matematyky profilnoi shkoly. (Innovations in the methodology of methodical training of the future teacher of mathematics of profile school). Pedahohika Vyshchoi ta Serednoi Shkoly, 40, 3-9.

Li, Y. (2012). Mathematics teacher preparation examined in an international context: Learning from the Teacher Education and Development Study in Mathematics (TEDS-M) and beyond. ZDM, 44(3), 367-370. https://doi.org/10.1007/s11858-012-0431-0

Martin, W.G., \& Gobstein, H. (2015). Generating a networked improvement community to improve secondary mathematics teacher preparation: Network leadership, organization, and operation. Journal of Teacher Education, 66(5), 482-493. https://doi.org/10.1177/0022487115602312 
Matiash, O., \& Mykhailenko, L. (2020). Opportunities for Method Competence Development of Mathematics Teachers: The Role of Participation in Competitions with Colleagues. Universal Journal of Educational Research, 8(3), 747-754. https://doi.org/10.13189/ujer.2020.080303

Matiash, O., Mykhailenko, L., Voievoda, A., Nakonechna, L., Kalashnikov, I., \& Olshevskyi, V. (2020). Usage of Information Communication Technologies for Training Prospective Mathematics Teachers in the Context of Dual System of Education in Ukraine. Universal Journal of Educational Research, 8(12). https://doi.org/10.13189/ujer.2020.081228

Matiash, O.I. (2015). Udoskonalennia profesiinoi pidhotovky vchytelia matematyky v umovakh kompetentnisnoho pidkhodu. (Improving the professional training of mathematics teachers in terms of the competence approach). Acta Universitatis Pontica Euxinus, pp. 241-246. Varna.

Matos, J.F., Powell, A., Sztajn, P., Ejersbø, L., \& Hovermill, J. (2009). Mathematics Teachers' Professional Development: Processes of Learning in and from Practice. In R. Even \& D.L. Ball (Eds.), The Professional Education and Development of Teachers of Mathematics (vol. 11). New ICMI Study Series. Springer, Boston, MA.

Motorina, V.H. (2005). Dissertation, Kharkiv.

Novotná, J., Bartolini Bussi, M.G., Beckmann, S., Inprasitha, M., Kaur, B., Sun, X.H., . . Askew, M. (2018). Professional Development Models for Whole Number Arithmetic in Primary Mathematics Teacher Education: A Cross-Cultural Overview. In M. Bartolini Bussi \& X. Sun (Eds.), Building the Foundation: Whole Numbers in the Primary Grades. New ICMI Study Series. Springer, Cham. https://doi.org/10.1007/978-3-319-63555-2_17

Potari, D. (2019). Theoretical and methodological tools in designing and analysing mathematics teacher education practices. J Math Teacher Educ, 22(4), 327-330. https://doi.org/10.1007/s10857-01909441-4

Potari, D., \& da Ponte, J. (2016). Current Research on Prospective Secondary Mathematics Teachers' Knowledge. ICME-13 Topical Surveys, pp. 3-15. https://doi.org/10.1007/978-3-319-38965-3_2

Schwarz, B., \& Kaiser, G. (2019). The Professional Development of Mathematics Teachers. ICME-1 $\overline{3}$ Monographs, pp. 325-343. https://doi.org/10.1007/978-3-030-15636-7_15

Shulman, L. (2013). Those who Understand: Knowledge Growth in Teaching. Journal of Education, 193(3), 1-11 https://doi.org/10.1177/002205741319300302

Skvortsova, S.O. (2010). Formuvannia profesiinoi kompetentnosti maibutnoho vchytelia matematyky. (Formation of professional competence of the future teacher of mathematics). Pedahohichna Nauka: Istoriia, Teoriia, Praktyka, Tendentsii Rozvytku, 4. Retrieved September 21, 2019, from http://intellectinvest.org.ua/pedagog_editions_emagazine_pedagogical_science_vypuski_n4_2010_st_4/

Springer Link. (2011). Measuring the mathematical quality of instruction. J Math Teacher Ed $\bar{d} u \bar{c}, 14,25-$ 47. https://doi.org/10.1007/s10857-010-9140-1

Strutchens, M.E. (2017). Current Research on Prospective Secondary Mathematics Teachers' Field Experiences. In The Mathematics Education of Prospective Secondary Teachers Around the World. ICME-13 Topical Surveys. Springer, Cham. DOI: 10.1007/978-3-319-38965-3_5

Tatto, M., Peck, R., Schwille, J., Bankov, K., Senk, S., Rodriguez, M., . . Rowley, G. (2012). Policy, Practice, and Readiness to Teach Primary and Secondary Mathematics in 17 Countries. Distributed by ERIC Clearinghouse.

Tatto, M., Schwille, J., Senk, S., Ingvarson, L., Peck, R., \& Rowley G. (2008). Teacher education and development study in mathematics (TEDS-M). Amsterdam, The Netherlands: IEA.

Thurm, D., \& Barzel, B. (2020). Effects of a professional development program for teaching mathematics with technology on teachers' beliefs, self-efficacy and practices. ZDM. https://doi.org/10.1007/s11858-020-01158-6 